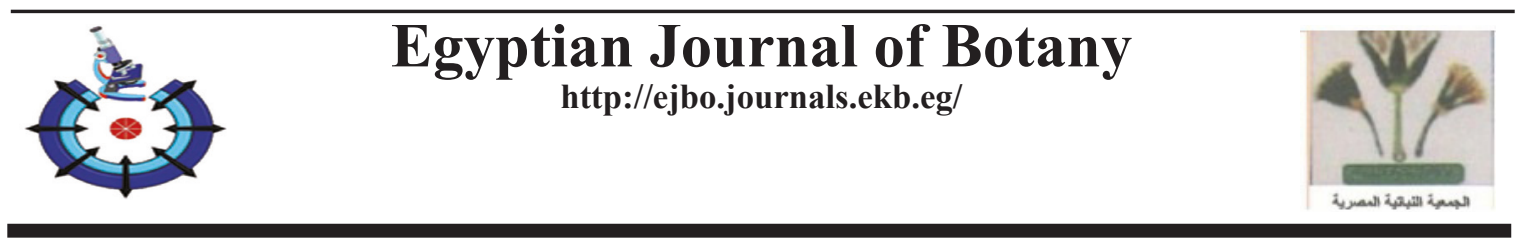

\title{
Eco-physiological Response of Solanum nigrum to Cd and Ni Stress under Hydroponic Conditions
}

\author{
Amany Aboelkassem ${ }^{(1) \#}$, Ahmed El-Khatib ${ }^{(1)}$, Somaya Hassanein ${ }^{(2)}$, Ola Allam ${ }^{(3)}$, \\ Omer El-Sheikh ${ }^{(1)}$ \\ (I)Department of Botany and Microbiology, Faculty of Science, Sohag University, \\ Sohag, Egypt; (2)Soils, Water and Environment Research Institute, Agricultural \\ Research Center (ARC), Giza, Egypt; (3)Soils, Water and Environment Research \\ Institute, Agricultural Research Center (ARC), Sohag, Egypt.
}

\begin{abstract}
COLANUM nigrum L. was transplanted from soil to hydroponic culture system with Hoagland's solution to study its eco-physiological response to $\mathrm{Cd}$ and $\mathrm{Ni}$ toxicity. The plants were exposed to 10 or $25 \mathrm{mg} / \mathrm{L} \mathrm{Cd}$ or Ni over 7 days before harvesting for analysis. The findings of this study provided better understanding of stress adaptation in $S$. nigrum under $\mathrm{Cd}$ and Ni stress. The photosynthetic pigments and activities of antioxidant enzymes were estimated in the plant leaves. Chlorophyll content and carotenoids decreased progressively with increasing concentrations of both metals. Activities of the antioxidant enzymes POD, APX, CAT, and SOD in the leaves increased significantly by exposure to the high levels for both metals. The plant responses was varied with both metal and tested concentrations, reflecting the potentiality of using S. nigrum as phytoremediator of $\mathrm{Cd}$ and $\mathrm{Ni}$ polluted water in hydroponic culture system.
\end{abstract}

Keywords: Antioxidant enzymes, Oxidative stress, Phytoremediation, Plant pigments, Stress tolerance.

\section{Introduction}

Aquatic habitats, especially fresh water ecosystems, are more contaminated than other environments because of water use for processes of industrial and residential waste disposal (Demirak et al., 2006; Fernandesa et al., 2007). Because of the possible harmful environmental effects of contaminants, this situation has become an environmental issue of major importance.

Physiological processes can be disrupted by heavy metals such as carbon assimilation decrease, inhibition of chlorophyll synthesis, generation of oxidative stress (Benavides et al., 2005; Gratão et al., 2008; Yusuf et al., 2011; Hussain et al., 2013; Selem, 2019). Excessive heavy metals are known to reduce photosynthetic apparatus performance and promote reduction in photosynthetic pigments includingchlorophyll and carotenoids production. (Fargasová, 2001; Ali et al., 2017).

More than 450 species of plants are referred to as hyperaccumulator plants. Such species, typically raise the problem of low biomass yield and growth rate (Verbruggen et al., 2009). Solanum nigrum has been reported to be growing in polluted sites around the world as hyperaccumulating of heavy metals. It also characteristic of being a fastgrowing, easy to adapt and has greater shooting biomass than most hyperaccumulators of metals (Marques et al., 2007).

As the phytoextraction using hyperaccumulators is seen as an innovative and competitive technique, the physiological responses of $S$. nigrum are important to be known in this highly toxic HM

\#Corresponding author email: aaboelkassem@yahoo.com $\quad$ Tel: 00201025840788, $\quad$ Fax: 0020934601159 Received 16/11/ 2019; Accepted 31/3/ 2020

DOI: $10.21608 /$ ejbo.2020.19487.1386

Edited by: Prof. Dr. Ahmed Kamel Hegazy, Faculty of Science, Cairo University, Giza 12613, Egypt.

(C)2020 National Information and Documentation Center (NIDOC) 
to provide a basic understanding of the biological mechanisms of metal hyperaccumulation and tolerance (Verbruggen et al., 2009; Wei et al., 2006). The oxidative stress caused by heavy metals in plants can occur through the production of active oxygen species (AOS) such as hydrogen peroxide $\left(\mathrm{H}_{2} \mathrm{O}_{2}\right)$, hydroxyl radicals $\left(\mathrm{OH}^{\circ}\right)$ and superoxide radicals $\left(\mathrm{O}_{2}^{-}\right)$(Qureshi et al., 2005; Ali et al., 2016; Rizwan et al., 2016; Ahmad et al., 2017). Such oxygen species induce lipid peroxidation, inactivation of the enzyme and destroy DNA structures, this reduces growth and productivity and that caused death of the plant (Dat et al., 2000; Gratão et al., 2005; Wang \& Zhou, 2006).

Antioxidant enzyme regulation provides additional defensive capabilities for plants against oxidative stress and generating AOS (Sun et al., 2007). Therefore, hyperaccumulators have an active tolerance strategy for heavy metals related to the expression of antioxidant enzymes under heavy metal stress (Boominathan \& Doran, 2003). Increased stress tolerance in metal-exposed plants is often associated with higher levels of antioxidants, particularly the increased activity of antioxidant enzymes, meanwhile, among the key antioxidant enzymes, superoxide dismutase stimulates the dismutation of ${ }^{\circ} \mathrm{O}_{2}^{-}$to $\mathrm{H}_{2} \mathrm{O}_{2}$ and $\mathrm{O}_{2}$, and forms, the first line of antioxidant defensive (Fidalgo et al., 2011, 2013; Gomes-Junior et al., 2006; Gratão et al., 2008). Different antioxidant enzymes, mainly found in peroxisomes, reduce the accumulation of $\mathrm{H}_{2} \mathrm{O}_{2}$ in cells. Peroxidase enzyme (POD) contributes in lignin biosynthesis and convert $\mathrm{H}_{2} \mathrm{O}_{2}$ to $\mathrm{H}_{2} \mathrm{O}$ is extremely important for plant respiration as well as $\mathrm{H}_{2} \mathrm{O}_{2}$ may be scavenged by Catalase (CAT) or peroxidases such as ascorbate peroxidase (APX) enzymes (Sun et al., 2007; Gajewska \& Slodowska, 2008; Hamed \& Abd Elgawad, 2018). The previous phytoremediation studies on $S$. nigrum were carried out on plants grown in soil. This study was designed to treat the species phytoremediation potentiality in hydroponic culture as an important asset for its future use in treating waste water for further use in raising hydroponic crops. The main objective of this study is to assess the potential effect of $\mathrm{Cd}$ and $\mathrm{Ni}$ on photosynthetic pigments and antioxidant enzymes activity in S.nigrum raised in hydroponic culture.

\section{Materials and Methods}

\section{Plant materials and growth conditions}

Seeds of Solanum nigrum L. were collected from a wild population growing in River Nile bank of Sohagcity. The seeds were germinated in Peat moss nutrient media for 2 weeks until they reached vegetative growth $3-5 \mathrm{~cm}$ high. The seedlings were transferred to plastic pots with clay-sandy soil for 2 months where they develop suitable biomass. Plants were then up-rooted by careful washing soil particles using tap water followed by distilled water before transformation to the hydroponic system (Fig. 1). The plants were kept to acclimatize for 3 days before heavy metal treatment (Cowgill \& Milazzo, 1989).

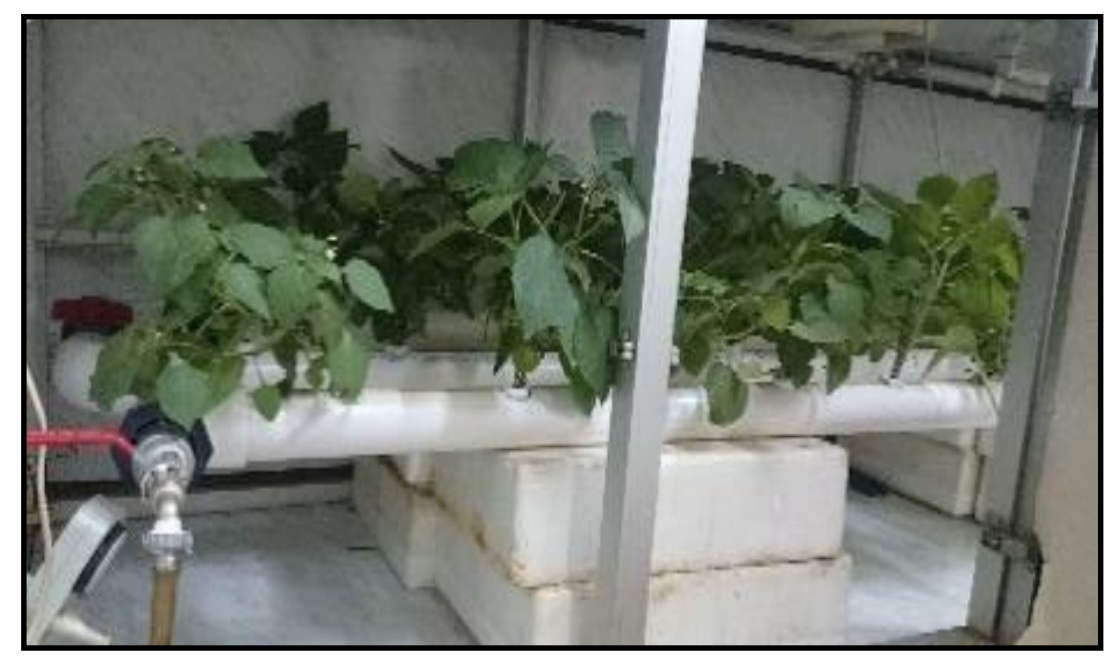

Fig. 1. Photo of the hydroponic system, the treatment solutions in the upper water tank (inlet) transferred through the three pipes into the lower water tank controlled by a timer switch. The solution in the lower tank was drained to the upper water tank to complete a water cycle [There were one water cycles every $24 \mathrm{hrs]}$.

Egypt. J. Bot. 60 , No.2 (2020) 
The water temperature in the hydroponic system was $22 \pm 2^{\circ} \mathrm{C}$ during the experimental time and the ambient air temperatures were $25^{\circ} \mathrm{C}$ day (14hrs) and $15^{\circ} \mathrm{C}$ at night. The light intensity of the day time was 1950 lux neon light. A ventilation system was designed to circulate the ambient air.

Based on the preliminary test results, initial concentrations (control, 10, 25mg/L) of the tested metals $\mathrm{Cd}$ and $\mathrm{Ni}$ were applied separately forevery metal. Nickel solution was prepared from $\mathrm{Ni}\left(\mathrm{NO}_{3}\right)_{2} \cdot 6 \mathrm{H}_{2} \mathrm{O}$ and Cadmium solution from $\mathrm{Cd}$ $\left(\mathrm{NO}_{3}\right)_{2} \cdot 4 \mathrm{H}_{2} \mathrm{O}$ (Sigma, St. Louis, MO). The plant and water samples were collected for consecutive 1, 3, 5, 7 days. The reagents were dissolved in 20 LHoaglandnutrient solution (Hoagland \& Arnon, 1938). Bidistilled water was used to achieve the appropriate contamination level in the hydroponic system.

\section{Photosynthetic pigments}

For determination of chlorophyll and carotenoids, the leaves of $S$. nigrum were extracted from $0.5 \mathrm{~g}$ of fresh leaves in $85 \%$ aqueous acetone. The leaf samples were grinded, centrifuged for $10 \mathrm{~min}$ at $5,000 \mathrm{rpm}$, the supernatant was completed to $10 \mathrm{~mL}$ with the aqueous acetone and the absorbance was measured at 452.5, 644, and $663.6 \mathrm{~nm}$ using spectrophotometer (Perkin Elmer Analyst 400, USA). The data were calculated according to Lichtenthaler \& Wellburn (1983) and expressed as $\mathrm{mg} / \mathrm{g}$ fw.

\section{Antioxidant enzymes}

Extraction and assays of antioxidant enzymes

Enzyme extraction was performed by grinding $0.5 \mathrm{~g}$ of fresh leaves at $4^{\circ} \mathrm{C}$ in $3 \mathrm{~mL}$ extraction buffer. The extraction buffer contain $50 \mathrm{mM}$ sodium phosphate buffer ( $\mathrm{pH} 7), 1 \%$ $(\mathrm{w} / \mathrm{v})$ polyvinyl pyrrolidone (PVP) and $0.1 \mathrm{mM}$ NaEDTA. The extract was subjected for centrifugation at $13000 \mathrm{rpm}$ for $20 \mathrm{~min}$ at $4^{\circ} \mathrm{C}$. The supernatants obtained were used to determine the enzyme activity.

Peroxidase enzyme (EC 1.11.1.7) activity was determined by mixing supernatants $(0.05 \mathrm{~mL})$ with assay mixture $(2.950 \mathrm{~mL})$ as described by MacAdam et al. (1992). Assay mixture containing $50 \mathrm{mM}$ Sodium, potassium phosphate buffer $(\mathrm{pH}$ $6.8), 5 \mathrm{mM}$ guaiacol and $0.3 \mathrm{mM} \mathrm{H}_{2} \mathrm{O}_{2}$. Oxidation of guaiacol was spectrophotometrically measured at $470 \mathrm{~nm}$. The activity was determined in terms of $\mu \mathrm{M}$ of oxidized guaiacol $\mathrm{min}^{-1} \mathrm{~g}^{-1}$ fresh weigh at $25 \pm 2{ }^{\circ} \mathrm{C}$ (Zhang, 1992).

Catalase enzyme (EC 1.11.1.6) activity was spectrophotometrically measured according to Aebi (1984). The activity of CAT enzyme was estimated by $\mathrm{H}_{2} \mathrm{O}_{2}$ consuming leading to a decrease in absorbance at $240 \mathrm{~nm}$ for $1 \mathrm{~min}$. The reaction solution contain $50 \mathrm{mM}$ sodium, phosphate buffer ( $\mathrm{pH} 6.8$ ), 20mM $\mathrm{H}_{2} \mathrm{O}_{2}$, and $0.1 \mathrm{~mL}$ enzyme extract. One unit of CAT is defined as the quantities of enzyme needed to decompose $1 \mu \mathrm{mol} \mathrm{min}{ }^{-1}$ of $\mathrm{H}_{2} \mathrm{O}_{2}$ under the assay conditions.

Ascorbate peroxidase, enzyme (EC 1.11.1.11) activity was measured as Nakano \& Asada (1981). APX activity was determined by using $3 \mathrm{~mL}$ assay media. It contained $50 \mathrm{mM}$ sodium, phosphate buffer ( $\mathrm{pH} 6.8$ ), $0.5 \mathrm{mM}$ ascorbate, $0.1 \mathrm{mM} \mathrm{H}_{2} \mathrm{O}_{2}$, $0.1 \mathrm{mM}$ NaEDTA and $0.05 \mathrm{~mL}$ enzyme extract. There was a decline in absorbance at $290 \mathrm{~nm}$ for $1 \mathrm{~min}$ resulted from the reduction in ascorbate concentration and the activity of the enzyme was measured using the extinction coefficient for ascorbate.

Superoxide dismutase enzyme (EC 1.15.1.1) was measured according to Giannopolitis \& Ries (1977) the activity of the enzyme was measured. SOD's ability to reduce the photochemical reduction of nitro blue tetrazolium (NBT) was determined for its activity determination. The reaction was performed in $3 \mathrm{~mL}$ reaction solution contains $50 \mathrm{mM}$ sodium phosphate buffer $(\mathrm{pH}$ $6.8), 2 \mathrm{mM}$ riboflavin, $13 \mathrm{mM}$ methionine, $75 \mathrm{mM}$ NBT, $100 \mathrm{mM}$ Na-EDTA and $0.05 \mathrm{~mL}$ enzyme extract. SOD activity was known as the quantity of enzyme that inhibit the photoreduction of nitro blue tetrazolium.

\section{Data analysis}

Data were subjected to statistical analysis using Minitab 17.0, where One-Way ANOVA followed by comparisons between means was employed. Linear regression was carried between each parameter and the concentrations of the metal and used to indicate the response of the plant.

\section{Results}

Photosynthetic pigments

The changes in the photosynthetic pigment chlorophyll and carotenoids in the leaves of $S$. nigrum treated with $\mathrm{Cd}$ and $\mathrm{Ni}$ are shown in Figs. 
2 and 3. Compared to the control, leaves of plants treated with $10 \mathrm{mg} / \mathrm{L}$ and $25 \mathrm{mg} / \mathrm{L}$ of $\mathrm{Cd}$ exhibited a significant decrease in Chl. a content of plants. The content of Chl. b and carotenoids decreased with time and $\mathrm{Cd}$ concentration increase in the nutrient medium as shown by the determinant coefficient $\left(\mathrm{R}^{2}\right)$ and Spearman's coefficient (r) values (Table 1). The Inhibitory effect of high level Cd $(25 \mathrm{mg} / \mathrm{L})$ was more pronounced on Chl. $\mathrm{b}$ and carotenoids than Chl. a when compared with the lower concentration $10 \mathrm{mg} / \mathrm{L}$. Compared with the control, Chl. a, b and carotenoids content in $S$. nigrum exhibited a similar response with a gradual decline at the two level of Ni concentration treatment. The maximum decline was attained after 7 days in the two tested concentrations as appear in $\mathrm{R}^{2}$ and $\mathrm{r}$ values in Table 1. Chlorophyll $\mathrm{b}$ decreased with increasing $\mathrm{Ni}$ concentration in the nutrient medium $(P<0.05)$, while the content of chlorophyll a and carotenoids showed insignificant response to $\mathrm{Ni}$ concentration from $10 \mathrm{mg} / \mathrm{L}$ to $25 \mathrm{mg} / \mathrm{L}(P>0.05)$.
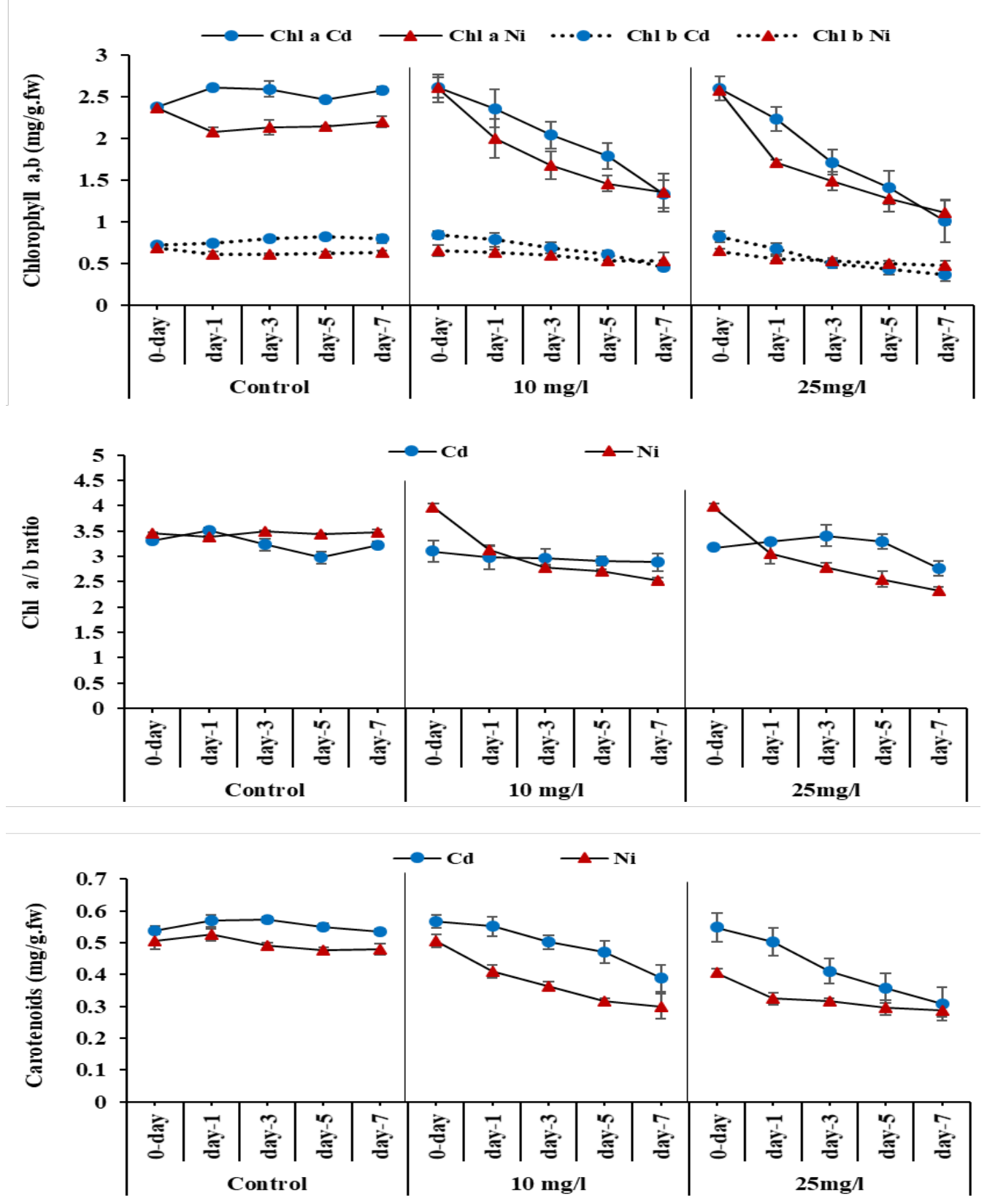

Fig. 2. Effect of Cadmium and Nickel treatment on photosynthetic pigments, chlorophyll a, chlorophyll b, Chl. a/b ratio and carotenoids in $S$. nigrum leaves.

Egypt. J. Bot. 60 , No.2 (2020) 
TABLE 1. Photosynthetic pigments responses $(\mathrm{mg} / \mathrm{g} . \mathrm{fw})$ and antioxidant enzymes activity (Unit/mg fw.min) of the tested enzymes in $S$. nigrum treated for 7 days with different concentratios of $\mathrm{Cd}$ and $\mathrm{Ni}(0,10,25 \mathrm{mg} / \mathrm{L})$ under hydroponic system $(n=9)$.

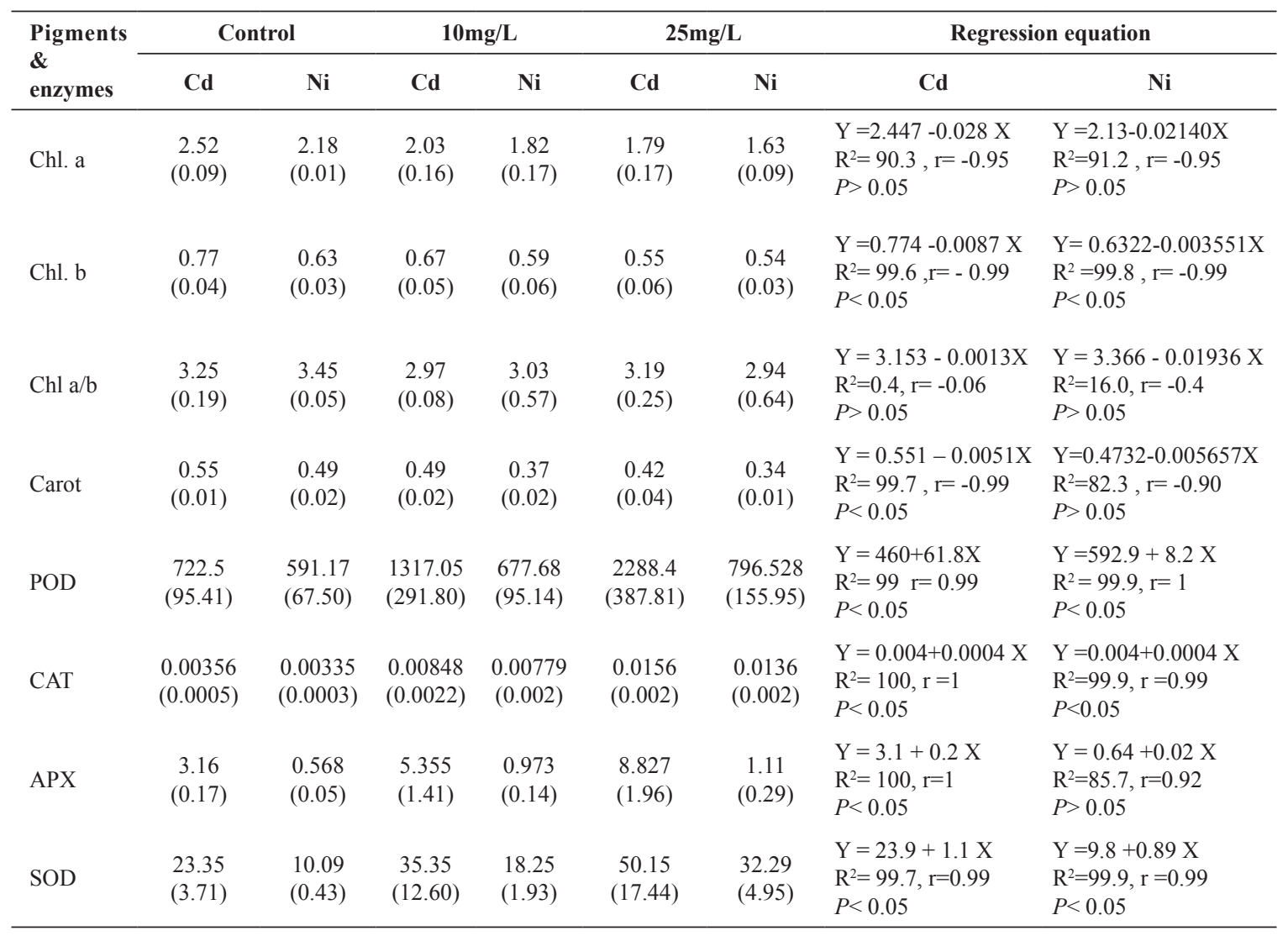

Numbers are mean \pm SD (values between bracets).

The ratios of chlorophyll $a / b$ were higher in the control than those in the treated growth medium (Fig. 2). The chlorophyll a/b ratio in $\mathrm{Cd}$ concentration of $10 \mathrm{mg} / \mathrm{L}$ significantly decreased with time $(P<0.05)$. Alternatively, that ratio was increased in the higher $\mathrm{Cd}$ concentration of $25 \mathrm{mg} / \mathrm{L}(P>0.05)$. The chlorophyll $\mathrm{a} / \mathrm{b}$ ratio in growth medium treated with $\mathrm{Ni}$ decreased significantly $(P<0.05)$ in the higher concentration $25 \mathrm{mg} / \mathrm{L}$ with time.

\section{Antioxidant enzymes}

The activity of Superoxide dismutase (SOD) in $S$. nigrum increased significantly with the increasing concentration of $\mathrm{Cd}$. The $\mathrm{Cd}$ treatments caused an increase in Peroxidase (POD), Ascorbate peroxidase (APX) and Catalase (CAT) activities with the time of the experiment duration (Fig. 4).

The enzymes activity increased with the increased $\mathrm{Ni}$ concentration, whereas CAT and SOD showed decrease in activity at the seventh day of the experiment of treatment (Fig. 4). The POD, CAT, and SOD activity increased with increasing Ni concentration $(P<0.05)$ compared with the control (Table 2). Alternatively, APX activity did not show an increase with the increase of $\mathrm{Ni}$ concentration. The $\mathrm{R}^{2}$ and $\mathrm{r}$ values confirm these correlations as shown in Table 1.

\section{Discussion}

The results of this study reflected the response of Solanum nigrum to $\mathrm{Cd}$ and $\mathrm{Ni}$ stress and their effects on pigment content and enzyme activity. As reported by Chandra \& Kulshreshtha (2004) and Qian et al. (2009), Cadmium-induced decreasing impact on chlorophyll and carotenoids content may be explained by its inhibitory effect on pigment biosynthesis enzymes directly or through the substitution of the central $\mathrm{Mg}$ ion. Also decreased chlorophyll a and chlorophyll $\mathrm{b}$ content in response to $\mathrm{Cd}$ results from the inhibition of chlorophyll biosynthesis resulting in senescence (Fang et al., 1998). These finding 
are in agreements with El-Khatib et al. (2011), who reported that the leaves of Ceratophyllum demersum and Myriophyllum spicatum under $\mathrm{Cd}$ stress showed decreased in their chlorophyll and carotenoid contents. Hence, chlorophyll pigments tend to be one of the main causes of plant heavy metal injury. This event reduced, synthesis of chlorophyll may also be due to the lack of access of essential nutrients for the plant's physiological activities (Fidalgo et al., 2011; Liu et al., 2013), where the rate of photosynthetic $\mathrm{CO}_{2}$ fixation decreases at high concentrations of heavy metal (Gao et al., 2010). This pigment decrease may also be due to inhibition of enzymes responsible for the chlorophyll synthesis (Cenkci et al., 2010; Pourraut et al., 2011). As reported by Bhattacharya et al. (2000), Cadmium was found to inhibit photosynthesis due to inhibition of chlorophyll synthesis. The decreased chlorophyll $\mathrm{a} / \mathrm{b}$ ratio with time indicates that the absorption band of mixed pigments extends toward the green part of the system (Fahmy et al., 1990). This means that the plant maximizes its photosynthetic activity in response to toxic metal stress.
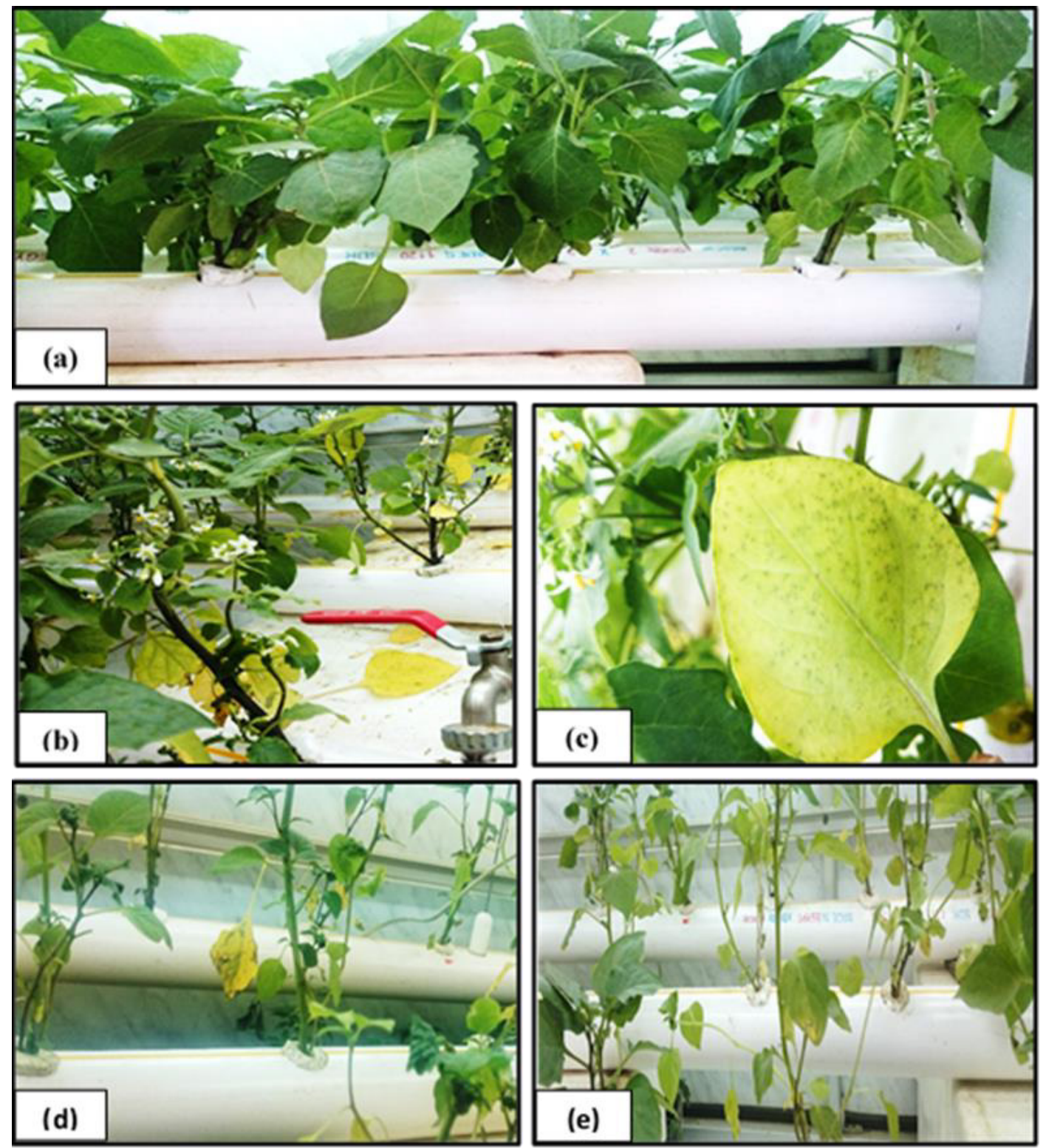

Fig. 3. Morphological variations in S. nigrum under heavy metal treatment; (a) control, (b and c) visual chlorosis, mosaic and leaf falling under Cd stress, and (d and e) visual chlorosis under Ni stress.

Egypt. J. Bot. 60 , No.2 (2020) 

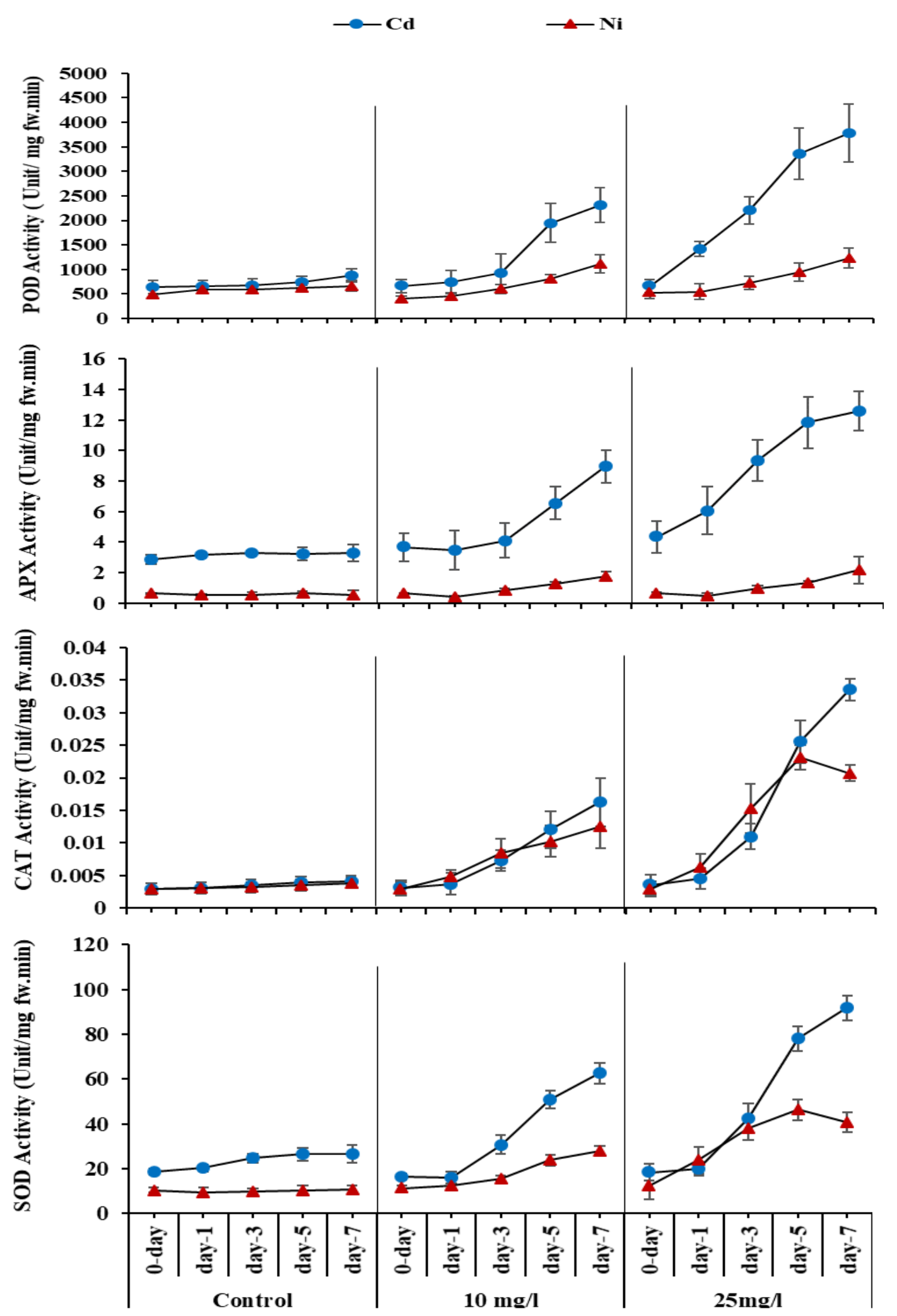

Fig. 4. Effect of Cadmium and Nickel treatment on antioxidant enzymes activity, POD, APX, CAT and SOD of $S$. nigrum. 
TABLE 2. Person's correlation matrix of the studied parameters with concentration of metals in plant tissue durig the experiment duration $(n=9)$.

\begin{tabular}{|c|c|c|c|c|c|c|c|c|}
\hline Metals & $\begin{array}{c}\text { Treatment } \\
(\mathrm{mg} / \mathrm{L})\end{array}$ & Chl. a & Chl. b & Carotenoid & POD & APX & CAT & SOD \\
\hline \multirow{2}{*}{$\mathrm{Cd}$} & 10 & $-0.95 * * *$ & $-0.94 * * *$ & $-0.95 * * *$ & $0.88 * * *$ & $0.93 * * *$ & $0.94 * * *$ & $0.97 * * *$ \\
\hline & 25 & $-0.97 * * *$ & $-0.95 * * *$ & $-0.97 * * *$ & $0.98 * * *$ & $0.98 * * *$ & $0.96^{* * *}$ & $0.95 * * *$ \\
\hline \multirow{2}{*}{$\mathrm{Ni}$} & 10 & $-0.86 * * *$ & $-0.83 * * *$ & $-0.81 * * *$ & $0.96^{* * *}$ & $0.98 * * *$ & $0.94 * * *$ & $0.94 * * *$ \\
\hline & 25 & $-0.78 * *$ & $-0.77 * * *$ & $-0.79 * * *$ & $0.96 * * *$ & $0.95 * * *$ & $0.70 * *$ & $0.63 *$ \\
\hline
\end{tabular}

**** Correlation is significant at the 0.001 level,${ }^{* *}$ Correlation is significant at the 0.01 level ., ${ }^{*}$ Correlation is significant at the 0.05 level.

Reduction in the levels of photosynthetic pigments, including carotenoids, on exposure to biotic or abiotic stressors was observed in many other species (Lau et al., 2006), where metals may affect carotenoids synthesis depending on metaltype and concentration (Singh \& Tewari, 2003).

Because $\mathrm{Cd}$ is a redox active metal, oxidative stress is caused by $\mathrm{Cd}$ toxicity, which may occur through production of ROS (Gratão et al., 2005). Plants enhance the antioxidant enzymes to scavenge ROS and prevent oxidative damage superoxide dismutase, Catalase, ascorbate peroxidase and peroxidase (Kanazawa et al., 2000). In contrast, Ni may not directly produce ROS, as it is not a redox-active metal. Ni can indirectly interfere with the responses of an antioxidant system (Ahmad et al., 2010; Gajewska \& Slodowska, 2008; Gill \& Tuteja, 2010). Even so, the results suggest that the activity of the antioxidant enzymes under $\mathrm{Cd}$ stress is higher than their activity under $\mathrm{Ni}$ stress.

High SOD activity associated with plant stress tolerance because it neutralizes the activity of superoxide radical that is over produced under metal stress. SOD is one of the stress-resistance enzymes, which can catalyze the conversion of two $\mathrm{O}_{2}^{-}$radicals to $\mathrm{H}_{2} \mathrm{O}_{2}$ and $\mathrm{O}_{2}$ (Foyer \& Noctor, 2000). Previous studies agree with these findings where Cd stress leads to an increase in SOD activity and this event was often associated with the increased plant tolerance (Deng et al., 2010).

The POD has many physiological functions including its role in lignin biosynthesis, building up a physical barrier against toxic heavy metals, participation in plant photosyn thesis, respiration, auxin metabolism, and virus resistance. Also, POD is considered as one of the key enzymes in the ROS removal, where its extra- and intracellular forms participate in the breakdown of $\mathrm{H}_{2} \mathrm{O}_{2}$. Elevation in POD activity in $\mathrm{S}$. nigrum treated with $\mathrm{Cd}$ suggests its role in the $\mathrm{H}_{2} \mathrm{O}_{2}$ detoxification (Dey et al., 2009). Enhancing POD activity in plants treated with excess $\mathrm{Cd}$ may result in either peroxidant damage to the thylakoid membrane or reduced auxin and protein content in tissues of plants (Sandman \& Boger, 1980; Sun et al., 2007).

Among the $\mathrm{H}_{2} \mathrm{O}_{2}$-destructive enzymes, $\mathrm{Cd}$ and Ni enhanced the activity of CAT and APX. The activity of CAT is essential for plant antioxidant defence system and cell protection (Shigeoka et al., 2002; Pandey, 2008; Xu et al., 2012). The present results are in agreement with the results on the other metal-accumulators Thlaspi caerulescens and Brassica juncea (Wang et al., 2008).

Eventually, the synthesis of antioxidant enzymes plays an important role in scavenging reactive oxygen species as an enzymatic protection system (Sharma et al., 2012). The results showed that S.nigrum has an effective tolerance strategy to $\mathrm{Cd}$, suggesting its strong internal detoxification mechanisms are a vital feature of Cd-hyperaccumulators (Boominathan et al., 2003).

Depending on the concentration, Ni seems to have dual effect as stimulating or inhibitory enzyme activities in plant tissues. Thus, another common mechanism of $\mathrm{Ni}$ toxicity is the increased activity of peroxidase, ascorbate oxidase, and catalase and superoxide dismutase with the increased concentration due to the formation of reactive oxygen species in plant cells, as well as elevating the activity of the antioxidant enzymes which protect plant cells against ROS toxicity (Schickler \& Caspi., 1999; Seregin \& Ivanov, 2001). But the activity of CAT and SOD enzymes was inhibited in the seventh day at $25 \mathrm{mg} / \mathrm{L}$ of $\mathrm{Ni}$ treatment causing decline in 
cell metabolism due to the inhibition of enzyme activities (Seregin \& Kozhevnikova, 2006). Also, the decline in antioxidant enzyme activities may result from accumulation of the reactive oxygen species, which may cause severe plant damage (Seregin \& Kozhevnikova., 2005; El-Khatib et al., 2014).

\section{Conclusion}

In conclusion, the present results suggest that the exposure of $S$. nigrum to high levels of $\mathrm{Cd}$ and $\mathrm{Ni}$ induce an appositive response by the antioxidant system. Various physiological mechanisms are involved as defense strategy against heavy metal accumulation effects. $S$. nigrum tolerates higher metal accumulation by modifying the antioxidant defense system. Our finding showed that the four major enzymes SOD, POD, CAT, and APX play an important role in the detoxification / elimination of ROS induced by $\mathrm{Cd}$ and $\mathrm{Ni}$, helping to alleviate the magnitude of stress onthe plant. These adaptive features of S.nigrum against the toxicity of $\mathrm{Cd}$ and $\mathrm{Ni}$ recommends its potential use in phytoremediation of polluted water in aquaculture agricultural systems.

\section{References}

Aebi, H. (1984) Catalase in vitro. Methods Enzymology, 105, 121-126.

Ahmad, M.S., Ashraf, M., Hussain, M. (2010) Phytotoxic effects of nickel on yield and concentration of macro- and micro-nutrients in sunflower (Helianthus annuus L.) Achenes. Journal of Hazardous Materials, 10, 234-240.

Ahmad, R., Ali, S., Hannan, F., Rizwan, M., Iqbal, M., Hassan, Z., Akram, N.A., Maqbool, S., Abbas, F. (2017) Promotive role of 5-aminolevulinic acid on chromium-induced morphological, photosynthetic, and oxidative changes in cauliflower (Brassica oleracea botrytis L.). Environmental Science and Pollution Research, 24, 8814-8824.

Ali, R.M., Mahmoud, M.H., Abbas, H.M., Marwa Fakhr (2017) Physiological studies on the interactive effects of Lead and antioxidants on Carum carvi plant. Egyptian Journal of Botany, 57(2), 317- 333.

Ali, S., Rizwan, M., Ullah, N., Bharwana, S.A., Waseem, M., Farooq, M.A., Abbasi, G.H., Farid, M. (2016) Physiological and biochemical mechanisms of silicon-induced copper stress tolerance in cotton (Gossypium hirsutum L.). Acta Physiologiae Plantarum, 38, 1-11.

Benavides, M.P., Gallego, S.M., Tomaro, M.L. (2005) Cadmium toxicity in plants. Brazilian Journal of Plant Physiology, 17, 21-34.

Bhattacharya, S.B., Saha, S.B., Basu, S., Chaudhary, A. (2000) Influence of heavy metals on the photosynthetic production of phytoplankton of mooriganga river, West Bengal. Journal of Environmental Biology, 21(2), 153-156.

Boominathan, R., Doran, P.M. (2003) Cadmium tolerance and antioxidative defenses in hairy roots of the cadmium hyperaccumulator, Thlaspi caerulescens. Biotechnology and Bioengineering, 83, 158-167.

Cenkci, S., Cigerci, I.H., YildIz, M., Özay, C., Bozdag, A., Terzi, H. (2010) Lead contamination reduces chlorophyll biosynthesis and genomic template stability in Brassica rapa L. Environmental and Experimental Botany, 67, 467-473.

Chandra, P., Kulshreshtha, K. (2004) Chromium accumulation and toxicity in aquatic vascular plants. The Botanical Review, 70, 313-327.

Cowgill, U.M., Milazzo, D.P. (1989) The culturing and testing of two species of duckweed. In: "Aquatic Toxicology and Hazard Assessment", Cowgill and L.R. Williams (Eds.), pp. 379-391, Vol. 12. ASTM STP 1027, U.M. American Society for Testing and materials, Phila.

Dat, J., Vandenabeele, S., Vranova, E., Van Montagu, M., Inze, D., Van Breusegem, F. (2000) Dual action of the active oxygen species during plant stress responses. Cellular and Molecular Life Sciences, 57(5), 779-795.

Demirak, A., Yilmaz, F., Levent Tuna, A., Ozdemir, N. (2006) Heavy metals in water, sediment and tissues of Leuciscus cephalus from a stream in southwestern Turkey. Chemosphere, 63(9), 14511458.

Deng, X., Xia, Y., Hu, W., Zhang, H., Shen, Z. (2010) Cadmium-induced oxidative damage and protective effects of $\mathrm{N}$-acetyl-1-cysteine against cadmium toxicity in Solanum nigrum L. Journal of Hazardous Materials, 180, 722-729.

Egypt. J. Bot. 60, No.2 (2020) 
Dey, S.K., Jena, P.P., Kunelu, S. (2009) Antioxidative efficiency of Triticum aestivum L. exposed to chromium stress. Journal of Environmental Biology, 30, 539-544.

El-Khatib, A.A., Hegazy, A.K., Abo-El-Kassem, Amany M. (2011) Induction of biomarkers associated with cadmium detoxification in aquatic species. Journal of Environmental Studies [JES], 7, 9-16.

El-Khatib, A.A., Hegazy, A.K., Abo-El-Kassem, Amany M. (2014) Bioaccumulation potential and physiological responses of aquatic macrophytes to $\mathrm{Pb}$ pollution. International Journal of Phytoremediation, 16, 29-45.

Fahmy, G.M., Hegazy, A.K., Hassan, H.T. (1990) Phenology, pigment content and diurnal change of proline in green and senescing leaves of three Zygophyllum species. Flora, 184, 23-436.

Fang, Z., Bouwkamp, J.C., Solomos, T. (1998) Chlorophyllase activities and chlorophyll degradation during leaf senescence in nonyellowing mutant and wild type of Phaseolus vulgaris L. Journal of Experimental Botany, 49, 503-510.

Fargasová, A. (2001) Phytotoxic effects of Cd, Zn, $\mathrm{Pd}, \mathrm{Cu}$, and $\mathrm{Fe}$ on Sinapis alba L. seedlings and their accumulation in roots and shoots. Biologia Plantarum, 44, 471-473.

Fernandesa, C., Fontainhas-Fernandes, A., Peixotoc, F., Salgadod, M.A. (2007) Bioaccumulation of heavy metals in Liza saliens from the Esmoriz Paramos coastal lagoon, Portugal. Ecotoxicology and Environmental Safety, 66(3), 426-431.

Fidalgo, F., Freitas, R., Ferreira, R., Pessoa, A.M., Teixeira, J. (2011) Solanum nigrum L. antioxidant defence system isozymes are regulated transcriptionally and post translationally in Cdinduced stress. Environmental and Experimental Botany, 72, 312-319.

Fidalgo, F., Azenha, M., Silva, F.A., de Sousa, A., Santiago, A., Ferraz, P., Teixeira, J. (2013) Copper-induced stress in Solanum nigrum L. and antioxidant defense system responses. Food Energy Secur, 2, 70-80.

Foyer, C.H., Noctor, G. (2000) Tansley Review 112. Oxygen processing in photosynthesis: Regulation and signaling. New Phytologist, 146, 359-388.

Gajewska, E., Sklodowska, M. (2008) Differential biochemical responses of wheat shoots and roots to nickel stress: Antioxidative reactions and proline accumulation. Plant Growth Regulation, 54, 179-188.

Gao, Y., Zhou, P., Mao, L., Shi, W.J., Zhi, Y.E. (2010) Phytoextraction of cadmium and physiological changes in Solanum nigrum as a novel cadmium hyperaccumulator. Russian Journal of Plant Physiology, 57, 501-508.

Giannopolitis, C.N., Ries, S.K. (1977) Superoxide dismutases: 1- Occurrence in higher plants. Plant Physiology, l(59), 309-314.

Gill, S.S., Tuteja, N. (2010) Reactive oxygen species and antioxidant machinery in abiotic stress tolerance in crop plants. Plant Physiology and Biochemistry, 48, 909-930.

Gomes-Junior, R.A., Moldes, C.A., Delite, F.S., Gratão, P.L., Mazzafera, P., Lea, P.J., Azevedo, R.A. (2006) Nickel elicits a fast antioxidant response in Coffea arabica cells. Plant Physiology and Biochemistry, 44, 420-429

Gratão, P.L., Polle, A., Lea, P.J., Azevedo, R.A. (2005) Making the life of heavy metal stressed plants a little easier. Functional Plant Biology, 32, 481-494.

Gratão, P.L., Pompeu, G.B., Capaldi, F.R., Vitorello, V.A., Lea, P.J., Azevedo, R.A. (2008) Antioxidant response of Nicotiana tabacum cv. Bright Yellow 2 cells to cadmium and nickel stress. Plant Cell Tissue and Organ Culture, 94, 73-83.

Hamed, B.A., AbdElgawad, H. (2018) Differential effects of some ascorbates on Phaseolus vulgaris L. in response to salinity stress. Egyptian Journal of Botany, 58(1), 23-36.

Hoagland, D.R., Arnon, D. (1938) The water culture method for growing plants without soil. UC College of Agriculture, Agricultural Experiment Station, Berkeley, CA. Circular, 347, 1-39.

Hussain, M.B., Ali, S., Azam, A., Hina, S., Farooq, A.M., Ali, B., Bharwana, A.S., Gill, M.B. (2013) Morphological, physiological and biochemical responses of plants to nickel stress: A review. African Journal of Agricultural Research, 8, 1596-1602.

Egypt. J. Bot. 60 , No.2 (2020) 
Kanazawa, S., Sano, S., Koshiba, T., Ushimaru, T. (2000) Changes in antioxidative in cucumber cotyledons during natural senescence: Comparison with those during dark-induced senescence. Plant Physiology, 109, 211-216.

Lau, T.S.L., Eno, E., Goldstein, G., Smith, C., Christopher, D.A. (2006) Ambient levels of UV-B in Hawaii combined with nutrient deficiency decrease photosynthesis in nearisogenic maize lines varying in leaf flavonoids: Flavonoids decrease photoinhibition in plants exposed to UVB. Photosynthetica, 44, 394-403.

Lichtenthaler, H.K., Wellburn, A.R. (1983) Determinations of total carotenoids and chlorophylls a and b of leaf extracts in different solvents. Biochemical Society Transactions, 11, 591-592.

Liu, J., Zhang, H., Zhang, Y., Chai, T. (2013) Silicon attenuates cadmium toxicity in Solanum nigrum L. by reducing cadmium uptake and oxidative stress. Plant Physiology and Biochemistry, 68, 1-7.

MacAdam, J.W., Nelson, C.J., Sharp, G.E. (1992) Peroxidase activity in the leaf elongation zone of tall fescue spatial distribution of ionically bound peroxidase activity in genotypes differing in length of the elongation zone. Plant Physiology, 99(3), $872-878$.

Marques, A.P.G.C., Oliveira, R.S., Samardjieva, K.A., Pissarra, J., Rangel, A.O.S.S., Castro, P.M.L. (2007) Solanum nigrum grown in contaminated soil: effect of arbuscular mycorrhizal fungi on zinc accumulation and histolocalisation. Environmental Pollution, 145, 691-699.

Nakano, Y., Asada, K. (1981) Hydrogen peroxidasis scavenged by ascorbate-specific peroxidase in spinach chloroplasts. Plant and Cell Physiology, 22 (5), 867-880.

Pandey, S.N. (2008) Growth and biochemical changes in pulse seedlings irrigated with effluent from electroplating industry. Journal of Applied Biosciences, 34, 79-82.

Pourraut, B., Shahid, M., Dumat, C., Winterton, P., Pinelli, E. (2011) Lead uptake, toxicity and detoxification in plants. Reviews of Environmental Contamination and Toxicology, 213, 113-136.
Qian, H., Li, J., Sun, L., Chen, W., Sheng, G.D., Liu, W. (2009) Combined effect of copper and cadmium on Chlorella vulgaris growth and photosynthesis related gene transcription. Aquatic Toxicology, 94, 56-61.

Qureshi, M.I., Israr, M., Abdin, M.Z., Iqbal, M. (2005) Responses of Artemisia annua L. to lead and salt induced oxidative stress. Environmental and Experimental Botany, 53, 185-193.

Rizwan, M., Ali, S., Qayyum, M.F., Ibrahim, M., Rehman, M.Z., Abbas, T., Ok, Y.S. (2016) Mechanisms of biochar-mediated alleviation of toxicity of trace elements in plants: A critical review. Environmental Science and Pollution Research, 23, 2230-2248.

Sandman, G., Boger, P. (1980) Copper mediated lipid peroxidation process in photosynthetic membranes. Plant Physiology, 63, 797-800.

Schickler, H., Caspi, H. (1999) Response of antioxidative enzymes to nickel and cadmium stress in hyperaccumulator Plants of genus, Alyssum. Physiologia Plantarum, 105, 39-44.

Seregin, I.V., Ivanov, V.B. (2001) Physiological aspects of cadmium and lead toxic effects on higher plants. Fiziol. Rast. (Moscow), 48, pp. 606-630 (Russian Journal of Plant Physiology, English Translation, pp. 523-544).

Seregin, I.V., Kozhevnikova, A.D. (2005) Distribution of cadmium, lead, nickel, and strontium in imbibing maize Caryopses. Fiziol. Rast. (Moscow), 52, 635640 (Russian Journal of Plant Physiology, English Translation, pp. 565-569).

Seregin, I.V., Kozhevnikova, A.D. (2006) Physiological role of nickel and its toxic effects on higher plants. Russian Journal of Plant Physiology, 53(2), 257277.

Sharma, P., Jha, A.B., Dubey, R.S., Pessarakli, M. (2012) Reactive oxygen species, oxidative damage and anti-oxidative defense mechanism in plants under stressful conditions. Journal of Botany, 2012, $1-26$.

Selem, Eman El-Sayed (2019) Physiological effects of Spirulina platensis in salt stressed Vicia faba L. plants. Egyptian Journal of Botany, 59(1), 185-194. 
Shigeoka, S., Ishikawa, T., Tamoi, M., Miyagawa, Y., Takeda, T., Yabuta, Y. (2002) Regulation and function of ascorbate peroxidase isoenzymes. Journal of Experimental Botany, 53, 1305-1319.

Singh, P.K., Tewari, R.K. (2003) Cadmium toxicity induced changes in plant water relations and oxidative metabolism of Brassica juncea L. plants. Journal of Environmental Biology, 24, 107-112.

Sun, R.L., Zhou, Q.X., Sun, F.H., Jin, C.X. (2007) Antioxidative defense and proline/ phytochelatin accumulation in a newly discovered $\mathrm{Cd}$ hyperaccumulator, Solanum nigrum L. Environmental and Experimental Botany, 60, 468476.

Verbruggen, N., Hermans, C., Schat, H. (2009) Molecular mechanisms of metal hyperaccumulation in plants. New Phytologist, 181, 759-776.

Wang, M.E., Zhou, Q.X. (2006) Joint stress of chlorimuron-ethyl and cadmium on wheat Triticum aestivum at biochemical levels. Environmental Pollution, 144, 572-580.
Wang, Z., Zhang, Y.X., Huang, Z.B., Huang, L. (2008) Antioxidative response of metal accumulator and non-accumulator plants under cadmium stress. Plant Soil, 310, 137-149.

Wei, S.H., Zhou, Q.X., Koval, P.V. (2006) Flowering stage characteristics of $\mathrm{Cd}$ hyperaccumulator Solanum nigrum L. and their significance to phytoremediation. Science of the Total Environment, 369, 441-446.

Xu, J., Sun, J., Du, L., Liu, X. (2012) Comparative transcriptome analysis of cadmium responses in Solanum nigrum and Solanum torvum. New Phytologist, 196, 110-124.

Yusuf, M., Fariduddin, Q., Hayat, S., Ahmad, A. (2011) Nickel: An overview of uptake, essentiality and toxicity in plants. Bulletin of Environmental Contamination and Toxicology, 86, 1-17.

Zhang, X. (1992) Research methodology of crop physiology. Agriculture Press: Beijing, China, 208211.

\section{الاستجابات الفسيولوجيا- بيئية لتبات عنب الايب المعامل بعنصري الكادميوم والنيكل تحث ظروف

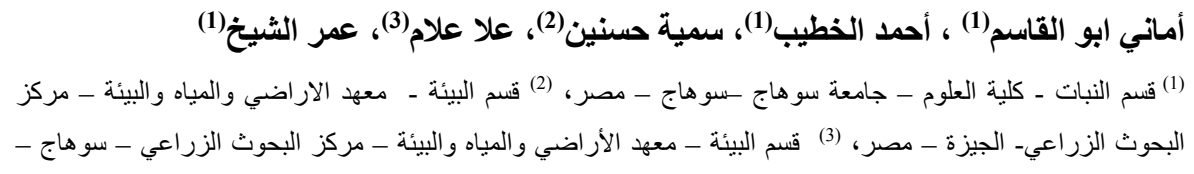

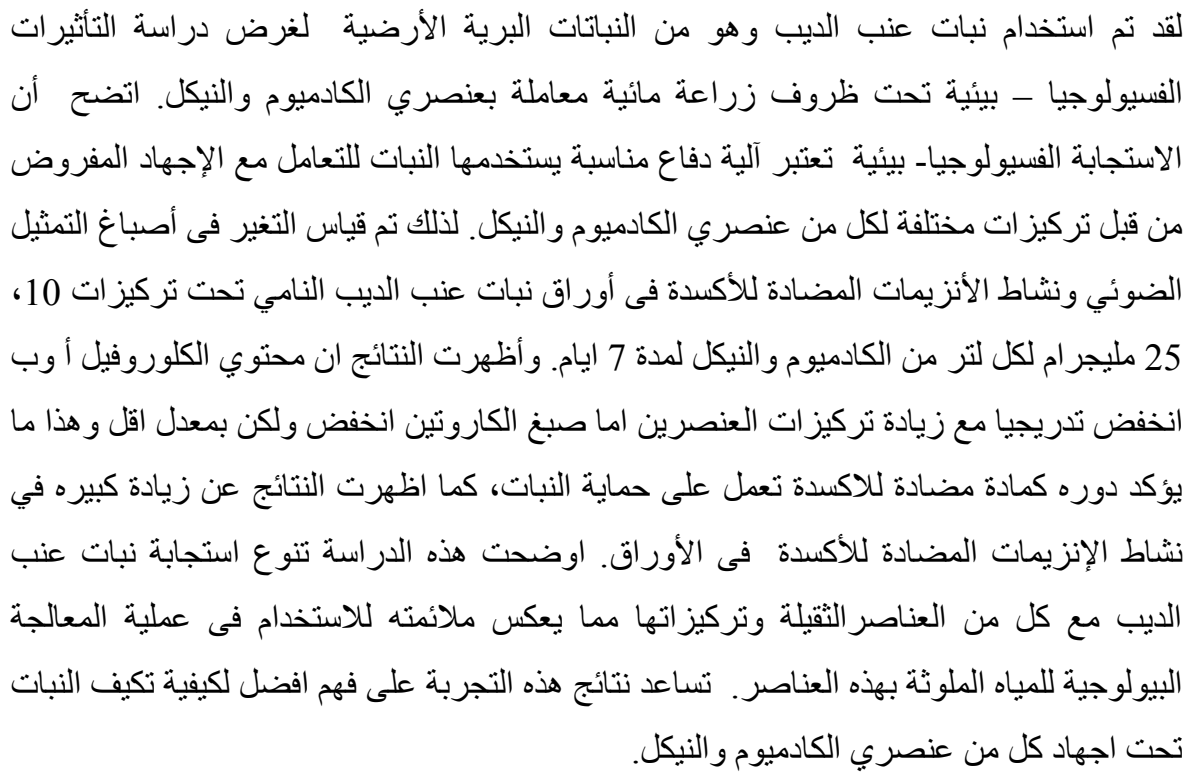

Egypt. J. Bot. 60 , No.2 (2020) 